\title{
The new genetics
}

The next link in the ecowelfare triangle concerns attention and sustainability. Again, there are many ways in which these two principles might connect. Of particular importance is the debate concerning geneticallymodified organisms (GMOs) and biodiversity. Does sustainability require the acceptance of the GMOs or their rejection in favour of organic production? How can we recognise and ensure the maintenance of biodiversity without losing the potential benefits of genetic technology? These are all worthwhile questions that others have begun to address over the last few years (Shiva, 2000a, 2000b) but, having concentrated upon 'external' nature in the preceding two chapters, I now want to concentrate upon 'internal' nature, since it is here that the implications for social policy are perhaps most pronounced. This chapter therefore refers back to Chapter 3 , where I argued that, in keeping with the advent of a security state, New Labour conceives of information as asocial, as commodified and as a source of surveillance. This chapter will discuss genetic information rather than information per se, but the aim is to construct an approach that resists these kind of priorities.

Some expect biotechnology to supplant the petrochemical and nuclear industries as the industry of the twenty-first century (Rifkin, 1998). If so, then before we can begin to yield the benefits of this technology we must prepare to avoid the accompanying dangers. Yet what are those dangers? For welfare egalitarians, the key danger is that the biological reductionism which often seems to be driving the technology shifts attention away from social explanations of human behaviour. In the present ideological climate, this means that biotechnology might help to consolidate the moral and market fundamentalisms of the Right (Knapp et al., 1996; Nelkin, 1999).

As such, this chapter takes issue with two recent interventions by prominent authors of the Right, Charles Murray and Francis Fukayama. 
The next section critiques Murray's position and the chapter then proceeds to argue that in order to prevent the emergence of 'laissez-faire eugenics', we must implement policies based upon a 'regulated eugenics', defending the contentious use of the term 'eugenics' along the way. The chapter then proceeds to examine the principles upon which a theory of regulated eugenics may be said to depend. We conclude by distinguishing regulated eugenics from the position taken by Fukayama.

\section{The new sociobiology}

Taking his cue from the sociobiology of Wilson (1998), Murray (2000; cf. Fukuyama, 1999: 97-101, 160-7, 227-30) contends that the new genetics is beginning to prove that the Right's view of human nature (as selfinterested, competitive, status-seeking, gendered and rule-governed) is the correct one. Consequently, the Right's prescriptions for social policy will also be shown to be accurate because, '... debates over social policy within the democratic west have also been underlain by conflicting understandings of human nature... The positions we adopt are based on assumptions about innate differences between men and women. The welfare state makes sense - or doesn't - depending upon underlying beliefs about how human beings achieve satisfaction in life' (Murray, 2000: 29). Since it will be demonstrated that men are innate hunter-gatherers and women are innate carers, one of the casualties of the new genetics will be the egalitarianism of the Left. In addition: '. . . when we know the complete genetic story, it will become evident that the population below the poverty line in the US has a configuration of the relevant genetic makeup significantly different from the configuration of the population above the poverty line' (Murray, 2000: 30). If humans are genetically different and unequal, then the case for social equality and distributive justice is fatally undermined. However, although the egalitarian Left will vanish, Murray anticipates a revival of the eugenic Left (cf. Singer, 1998). Invoking the legacy of Shaw, Goldman, Wells and the Webbs, Murray fears that dirigiste genetic engineering will offer the greatest threat to personal liberty in the twenty-first century, driven (once their interpretation of human nature has been disproved) by little more than the Left's propensity to interfere in the natural order.

Murray can be criticised on any number of grounds (cf. Kohn, 2000). It could be argued that the new genetics will not prove or disprove human nature to be one thing or another. Murray's faith in the innateness of femininity and masculinity is based upon a conceptual confusion: he talks of the interaction of biology and environment, but also of how human nature produces social and political institutions. Yet if biology and envi- 
ronment interact, then institutions must also be said to produce human nature to some degree. There is an even more invidious confusion. Murray proposes that the revelation of genetic differences between groups (men/women, white/black, English/French) is relatively insignificant: 'so what?', he proclaims, and 'vive la différence'. Yet how does this square with Murray's declaration that the poor are genetically different from the non-poor, especially in the light of his previous observations that the large parts of the poor constitute a semi-criminal underclass (Murray, 1984, 1990)? Either those genetic differences are innate, in which case Murray's 'vive la différence' attitude contradicts his infamous condemnations of welfare dependency, or they are the product of the welfare state gradually undermining the work ethic of the poor, in which case (whether you agree with that view or not) human nature must be an historical and environmental construct, according to Murray's own logic. And if a large proportion of the 'undeserving poor' are black, then Murray's confusion quickly shades into academic racism (Herrnstein and Murray, 1994).

As such, egalitarian and social explanations of human behaviour are not disproved by the new genetics per se (although there is a risk of their being drowned out by an alliance of biotechnology and biological reductionism) and Murray's distinction between market individualism and Leftist state eugenics (with the former defending us from the latter) is revealed as being a crude distortion. Indeed, Murray himself states that, 'The popular voluntary uses of gene manipulation are likely to be ones which avoid birth defects and ones that lead to improved overall physical and mental abilities. I find it hard to get upset about that prospect (Murray, 2000: 31). But Murray does not seem to realise that there are two prospects here: avoiding birth 'defects' (and who is to decide what a defect is?) may improve abilities, but what if the improvement of abilities is the direct aim of affluent parents and profit-driven biotechnology companies? Presumably, if the wealthiest can afford the genetic enhancements and medicines that will be unavailable to those on low incomes, then social and genetic inequalities may feed into each other in a vicious downward spiral, a new race to the bottom. If, like Murray, the Right are generally unmoved by this possibility, then we have reason to believe that the main danger comes not from any statist eugenics of the Left, but from a 'laissez-faire eugenics' (Kitcher, 1996; Duster, 1990) of the Right.

Murray's analysis is therefore potentially useful in at least two senses. First, he is correct to note the importance of human nature, although it might be more accurate to claim that human nature and social policy underpin one another; for if biology and environment really do interact, then human nature is as much a product of social policy as the latter is a product of the former. Identifying a single causal flow from one to the other may be an impossible exercise to perform. Second, Murray's dis- 
torted analysis nevertheless opens up a conceptual space that needs to be filled. If laissez-faire biotech commercialism and statist eugenics lie at the extremes of the genetic spectrum, rather than, as Murray would have it, at adjacent points on the compass, then there is a middle ground that we urgently need to debate and define.

\section{Eugenics}

How then might welfare egalitarians resist laissez-faire eugenics? The premise of the following argument is as follows. If genetics deals with heritable characteristics, then eugenics denotes the attempt to determine what should and should not be heritable from one generation to the next. The eugenics which flourished in the first four decades of the twentieth century was the misguided attempt to impose order upon what was perceived as genetic chaos and contingency. In a world of Empires, scientific materialism and aristocracy, the idea that 'chance' prevailed over 'choice' was unbearable to many on both Left and Right. Far easier to distinguish between the degenerate and the non-degenerate and to recommend the sterilisation of the former and the selective breeding of both groups. Although hardly anyone now wishes to revive these kinds of assumptions and policies, it is also the case that, due to the advent of biotechnological innovations, we cannot avoid making difficult choices about the genetic characteristics of future populations. Even if we today erased our knowledge of genetics for all time, we would still be making a choice, i.e. that the genetic characteristics of future populations should be shaped through complete non-intervention. Therefore the real decision we have to face is not between eugenics and non-eugenics, because we cannot choose not to choose, but between a eugenics of the free market (where it is the unintended outcomes of voluntary exchanges that shape future populations) and a eugenics that is set within regulatory frameworks. In short, a regressive eugenics (whether based upon the centralised state or the free market) is one that elevates choice over chance, whereas a progressive, regulated eugenics makes room for both choice and chance in its values and criteria.

Before defending my use of the word eugenics, let me illustrate this point with what is at the time of writing a recent example. In April 2002 it was revealed that a couple in America were planning to conceive a baby who like them would be born deaf. They did so on the grounds that the deaf community had formed a distinct cultural identity and that any child they had would therefore be impoverished unless it too shared that identity. To those who objected, they countered that just as it would be racist to condemn a black couple for conceiving a black baby so it was disablist 
to condemn a deaf couple for conceiving a deaf baby. I do not want to discuss the rights or wrongs of this case (though I personally believe such decisions to be immoral), but to observe that such bioethical dilemmas are likely to become more and more frequent and that, whatever solution we prefer, we cannot avoid the eugenic implications. If we allow such couples a free choice, then we are effectively permitting a laissez-faire eugenics along the lines that Murray seems to countenance. If we ban them, then we either have to rule out all forms of genetic manipulation (including those that may improve well-being) or we have to distinguish between moral and immoral uses, which means making some difficult decisions about future generations. If we prefer leaving it to nature, then we are in effect disinventing the technology and so making a decision under the cover of a non-decision. In short, whichever way we turn we cannot avoid the necessity of making a choice. And when 'choice' joins 'chance' in determining future generations' characteristics, then we are dealing with eugenics.

Now, while acknowledging the dilemmas, we will increasingly face, many will understandably quail at this use of the term. Surely it is far easier and safer to associate eugenics with the fascistic attempt to purge the human population of 'biological impurities'. Those with whom I have debated these issues often prefer a term such as 'genetic justice'. Unfortunately, in occupying the moral high ground in this way, we do not thereby avoid the difficult decisions that need to be made. Tom Shakespeare (1998: 668), for instance, defines eugenics as 'the science of improving the population by control of inherited qualities' and goes on to argue that, 'In those rare cases where impairment causes inevitable neonatal death or permanent lack of awareness, it might be more appropriate to screen out such conditions prenatally. Absolutist positions - abort all impaired foetuses, or ban all termination on the basis of impairment are equally unhelpful to women and men making very difficult decisions about reproductive choices' (Shakespeare, 1998: 670). This is certainly true and seems to invite policies based upon 'weak eugenics' as opposed to the 'strong eugenics' of state coercion (cf. Glover, 1999: 104). And although they would permit far more genetic engineering than Shakespeare, Buchanan et al. (2000) come to a similar conclusion: '. . just as the state is the principal agent acting in the interests of future generations in such fields as land and resource management, so too does a eugenic role for the state, if needed, fit into the standard categories of legitimate areas of concern for government' (Buchanan et al., 2000: 337). All of which is both to agree and disagree with Diane Paul (1998: 94-111) when she insists that the distinction between eugenic and non-eugenic policies is fading. For Paul, this means that those who embrace and those who reject the concept are both missing the point as to how we can now learn from the past. If it 
were possible to apply a substitute concept that (1) confronted the moral dilemmas of biotechnology and (2) avoided the negative connotations of 'eugenics', then I believe we should do so. To my mind, 'genetic justice' satisfies (2) but not (1), since it allows us to keep our moral hands clean in an area where, like Lady Macbeth, our hands promise to be both very clean and very dirty indeed (Kitcher, 1996; Glannon, 1998).

So if the avoidance of extreme impairment leads by definition to the improvement of social welfare, then although we can run away from the word 'eugenics', we cannot run away from the responsibility of deciding which reproductive choices are and are not acceptable. Indeed, if we run away from the word, then our genetic practices may be more likely to replicate the abuses of the past - as happened with the Scandinavian sterilisation programmes of the 1930s-1970s (Broberg and Roll-Hansen, 1996). This means that, whatever our decision, we can now intervene in that biology-environment interaction more directly than ever before (Dickens, 2000: 116). Social policy is no longer just about fulfilling needs from cradle to grave, it is also about deciding which needs are to exist in the first place by either intervening or deciding not to intervene before the cradle. It is no longer a question of simply fitting social policies to human nature, but of using social policies as a way of determining what human nature will be (Engelhardt, 1996). In the biotech age, we must peer deeper into history's hall of mirrors and recognise the eugenic reflections that are staring back.

Therefore, the essential choice is not between eugenics and noneugenics, nor between free markets and statist eugenics (as Murray believes), but between a laissez-faire eugenics and the 'regulated eugenics' supported by Kitcher (1996; Glannon, 1998: 204-6). Regulated eugenics allows the elimination of those genetic conditions the experience of which does not allow the bearer to enjoy a minimal quality of life and formulate a sense of him or herself. This means that there are some conditions that should be eliminated, e.g. Hurler syndrome and Tay-Sachs, but others which should not, e.g. Down syndrome limits but does not eliminate selfdevelopment. Of course knowing where to draw the line is the dilemma. Can regulated eugenics guide us through this dilemma? This chapter now argues that regulated eugenics rests upon three 'supports': a multidimensional conception of human nature, a principle of differential egalitarianism and the precautionary principle.

\section{Social policy and human nature}

If a regulated eugenics is to shape those many social policies that will relate to biotechnology and the new genetics (hereafter known as 'biopolicies'), it stands to reason that we must elaborate an appropriate view of 
human nature. To date, the subject of social policy has worked with four main conceptions of human nature.

The 'unidimensional' conception proposes that human nature is largely defined by a single characteristic, i.e. altruism or self-interest. Social democrats have often believed individuals to possess a fundamental altruism that is suppressed by market capitalism, but which would flourish once appropriate social and economic reforms were in place (Titmuss, 1970: 209-24; cf. Baldwin, 1990). In the post-classic era by contrast, we have been exposed to new versions of those doctrines that stress individualistic self-interest in the form of a strange blend of market libertarianism and moral conservatism.

Second, there have been constructivist conceptions which challenge the belief that there is any pre-social human nature. For post-structuralists (Foucault, 1984), the relevant question is not 'What is human nature', but 'Why do some groups believe human nature to be $x$, others $y$ and others $z$, and how do the prevailing conceptions change over time?' This genealogical approach looks beyond the liberal humanist self to the discourses and practices that constitute the field of the self's construction.

Lying between these two conceptions is a 'multidimensional' conception which identifies human nature as to some degree an extra-historical condition that is founded upon a plurality of subject positions and which can take any one of a series of forms depending upon the social properties of the historical context. For instance, Hewitt (2000) argues that four models of human nature are identifiable from the social policy literature - the atomistic, the organic, the basic needs and the mutualist models and that these have been 'sutured' together in a variety of ways depending upon the institutional principles and practices that prevail.

The final conception is agnostic, recommending that we bracket the debate and take a practical approach to social reform that addresses specific objectives without reference to the metaphysical foundations of social policy. Le Grand $(1997,2000)$ has recently argued in favour of a creative ignorance regarding human motivation as a means of leap frogging the sterilities of the selfishness/altruism debate. Such creative ignorance can then give rise to robust welfare strategies that can appeal to a host of human motivations and ideological prescriptions.

Which of the above should we prefer? If laissez-faire eugenics is what we ought to avoid, and if Murray's biological reductionism (where human nature 'produces' institutions) opens the door to such eugenics, then perhaps the regressive consequences of biotechnology can be best resisted by a conception of human nature that challenges biological reductionism.

Biological reductionism is an umbrella term for a series of similar disciplines - sociobiology, evolutionary biology, behavioural genetics, evolutionary psychology - that share some basic premises and methodologies 
(cf. Rose, 1997: 280-95). First, self-replication and reproduction are regarded as the goal to which all lifeforms are driven. For Dawkins (1989), organisms or phenotypes are vehicles and survival machines through which genes copy themselves into the next generation. Second, therefore, not only are genes treated as biological atoms, distinct entities that can be abstracted from the genome, but they are programmed to be selfinterested: the function of a gene is to give birth to other genes that will outlive it. ${ }^{1}$ Finally, organic processes consist of endless adaptation to the environment as natural selection carves away those features of the phenotype that are biologically redundant.

The attraction of biological reductionism is that it offers a simple explanation of life that nevertheless takes account of life's complexity: the environment is treated as an important dimension of species evolution. However, those such as Gould (1978: 231-67), Rose et al. (1984), Rose (1997) and Lewontin (1993) warn us against the reductionism of those such as Wilson $(1975,1998)$, Dawkins $(1982,1989)$, Pinker (1995), Dennett (1996) and Ridley $(1996,1999)$ in what has become known as the Darwin wars (Brown, 1999).

For 'Critical Darwinians' such as Gould, biological reductionism represents an undesirable shift away from environmental explanations of life, all the more so because it comes at a time when politics and economics have been blowing in the same direction, towards pathological explanations that neglect interactionist processes and invite biotechnological fixes to social problems. They argue that we cannot assign explanatory priority to either genes or the environment, as they are inseparable both physically and conceptually. Biological reductionism invites either a passivity in the face of social injustice, e.g. patriarchy is often attributed to innate biological differences, or simplistic approaches to genetic engineering, and often both at the same time (Ridley, 1999: 217-18, 253). The Critical Darwinians therefore draw our attention to the superficial ways in which reductionism deals with environmental factors; genes, in Wilson's (1978: 172) famous phrase, 'hold culture on a leash' and Dawkins (1989: 189-201) went as far as proposing that there is a cultural equivalent of the gene, the 'meme' (Blackmore, 1999). Reductionists also treat altruism as equivalent to nothing more than reciprocity, i.e. a product of enlightened self-interest (Axelrod, 1984).

This takes us to the central problem (Rose, 1997: 213-14): biological reductionists usually want to have it both ways. They want to identify self-interested genes as the determining foundations of human behaviour (Watson, 1998); yet, in order to avoid the charge that reductionism legitimates the selfish status quo, they also propose that we can rebel against our genes if we desire (Pinker, 1995). But how is this possible? If genes really are that important, then how can we rebel against them? On 
the other hand, if we can rebel against them, then this means either that it is the genes themselves that permit such rebellion, implying that they are not purely self-interested, or that they are not so important after all and that some other factor is at work. In short, if genes are (1) selfinterested and (2) the key determinants of human behaviour, then we cannot rebel against them, whereas if we can rebel then either (1) or (2) must collapse.

If biological reductionism is caught on the horns of a contradiction, then what might this 'other factor' be? According to Critical Darwinians it has to be culture (cf. O'Hear, 1997). The reductionists tend to interpret culture in terms of its biological origins and so neglect the specificity of cultural history: the reflexive learning processes of civilisation; but for Gould and other Critical Darwinians culture cannot be reduced to its biological origins because it is a space of cooperative interdependency through which humans transcend their genetic endowments and construct themselves as free beings who determine the conditions of their own future development. Humans have created their own freedom as cultural cooperativists, meaning that the structure of human freedom has long since floated free of its biological base. This brings us neatly back to social policy and human nature.

In what ways can social policy help to resist the siren voices of biological reductionism? What might a criticalist perspective suggest? It is unlikely that the unidimensional conception can do so. Indeed, those who subscribe to the view that humans are inherently selfish might well welcome biological reductionism; and although an appeal to inherent altruism is laudable (Page, 1996), 'pure' altruism is undoubtedly less frequent than the 'reciprocal altruism' that the reductionists profess to explain with constant reference to genetic self-interest. The constructionist conception is of little help either, as this rejects the notion of a pre-social human nature altogether and offends against the commonsense view that there must be something over and above the social constructions out of which the particular self is woven. The robust strategy is also redundant. To suggest that policies can be detached from their metaphysical foundations is at best wishful thinking and at worst a surrender of the academic subject's traditional task of combating injustice.

Therefore the multidimensional conception which is perhaps of most assistance in resisting biological determinism. Its strength is that it interprets human nature and motivation as unsettled, as hovering in an indeterminate 'liminal' space between a number of plausible narratives. So although both self-interest and altruism may be invoked, this conception adopts an overdetermined reading of these and other coherent narratives so that human nature is an 'emergent property' that constantly evolves beyond the sum of its immediate parts (Schwartz, 1997). The multi- 
dimensional theory acknowledges that there is a pre-social metaphysical ground to human nature, but argues that because we understand this ground through a constructivist kaleidoscope of interpretivist narrations, then we can only ever possess an indistinct grasp of what that pre-social nature might actually be. Therefore we can recognise the importance of our genetic endowments without assigning the excessive weight to them that is promoted by the reductionists.

The first 'support' is therefore in place. If laissez-faire eugenics is based upon a biological reductionism, where the social environment matters little, then any viable alternative must derive from an epistemology which is both realist and constructivist. Yet if regulated eugenics is based upon a multidimensional conception of human nature, then how does it begin to translate into actual social policies? This is a question that we can only answer fully once we have addressed the following: what is the relationship between eugenics and the welfare state?

\section{Eugenics and the welfare state}

The final two supports depend substantially upon the kind of values that have long motivated the most progressive and humane aspects of social policy, e.g. equality, liberty, welfare. However, these values are not, in themselves, sufficient and at least two additions must be made: difference and precaution. To illustrate why this is the case, we need to briefly review the relationship between eugenics and the welfare state.

While it would be facile to regard state welfare as an essentially eugenic institution, eugenic beliefs formed the background to the early years of modern social policies to such an extent that it seems equally facile to downgrade their importance in influencing reform (Thane, 1996: 60; cf. King, 1999: 51-96), though eugenics undoubtedly had fewer direct affects upon British legislation than upon that of other countries (Drouard, 1998). So what influence did eugenics have upon the early formation of British state welfare? There are two axes in Figure 8.1. The horizontal line is the descriptive axis that refers to the possible strength of the eugenic influence upon the welfare state; the vertical line is the normative axis which articulates the fact that eugenics was supported by both egalitarians and inegalitarians. This leaves us with four quadrants into which we can fit six theoretical interpretations. (Note that this taxonomy is not intended to distil the history of early modern social policy; it is merely establishing that a case can be made for identifying a eugenic influence upon that history.)

Interpretation (1) articulates the view that eugenics exerted only a weak influence because its doctrine of social inequality contradicted the egali- 
Figure 8.1 Eugenic influences on the early welfare state

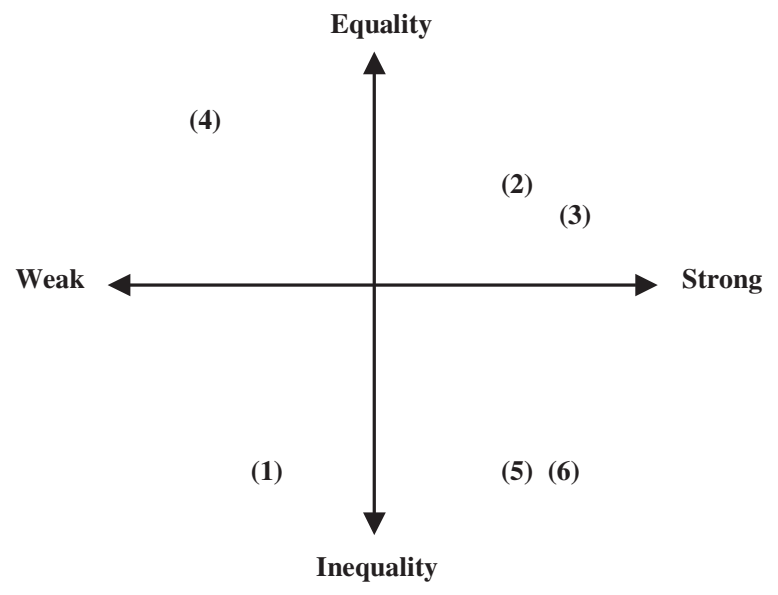

tarian commitments of state welfare (Kevles, 1985: 99; Thomson, 1998: 29-35). This interpretation corresponds to the theory of social Darwinism, where the welfare state represents a successful but regrettable counterreaction to eugenics that was to make 'biological degeneracy' appear normal and acceptable. Therefore the welfare state's regulation of the economy and deregulation of sexual mores reverses the social Darwinist's commitment to laissez-faire economics and the state control of reproduction.

Interpretation (2) states that the influence was strong because both eugenics and the welfare state promote social equality. The most appropriate theory here is a 'reform eugenicism' that favourably identifies a convergence of welfare state and eugenic principles. The recruitment experience of the Boer War (Searle, 1976: 22-4, 34-44) inspired some to believe that a combination of state welfare and eugenic assumptions was required to avoid national deterioration (Kevles, 1985: 91-2). Of relevance in this respect is the rarely-cited analysis of Marshall (1953: 85; cf. Oakley, 1991) that the egalitarian citizenship of the welfare state would underpin the social inequalities that reflected the natural inequalities which eugenic science had successfully identified.

Interpretation (3) substantially agrees with (2), but is more a theory of 'population eugenicism'. Restrictive Victorian morality, it was argued, meant that many spouses were mismatched, so that the children they produced were genetically less fit than they might otherwise have been (Kevles, 1985: 65-6). Therefore eugenic improvement required the sexual liberation of women and/or an army of stay-at-home mothers who would 
ensure their children's genetic fitness (Searle, 1976: 86-90). From here, it is a short leap to the view that systems of birth control, family planning and family allowances are needed to encourage low-income women not to breed excessively (Thomson, 1998: 64-6). ${ }^{2}$

Interpretation (4), however, regards the eugenic influence upon the welfare state as weak, because the former is more egalitarian than the latter. Here we find theories of 'statist eugenicism' which argue that, although distinctions should be made between the genetically inferior and superior, these do not correspond to that between the lower and the upper classes (Kevles, 1985: 86-7): biological inferiority appears at all levels of the social scale. For many early socialists, state welfare was only the first step towards the classless, egalitarian society that was needed if human evolution was to proceed without the burden of the undeserving rich (Thomson, 1998: 200-1). This second step has never been taken however, so that the eugenic influence has ultimately been negligible.

Interpretation (5) expresses the view that the eugenic influence has been strong because both it and the welfare state are based upon a fundamental social inequality. The theory of 'statistical eugenics' states that mental tests can distinguish between the genetically superior and inferior (Gould, 1978), and it is such mental tests that have worked their way into significant quarters of the welfare state (Eysenck, 1998; Mensch and Mensch, 1990; Selden, 1999).

Finally, interpretation (6) concurs about the joint inegalitarianism of eugenics and state welfare and corresponds to the theory of 'penal eugenics'. Some argue that both eugenics and state welfare constituted twin strategies of disciplinary control. Garland (1985: 130-55) insists that we need to identify substantial continuities between the nineteenth-century minimalist state and the post-Victorian 'penal-welfare' state. He underlines the extent to which eugenics inspired the modern system of social security, so that the latter is the institutional embodiment of the genetic endowments we are assumed to possess. According to this interpretation, social policy prods the genetically unfit into labour colonies, workfare and social assistance schemes (King, 1999) and designs labour exchanges and social insurance systems for the genetically fit.

Taken individually, none of the above interpretations is entirely satisfactory, yet, when taken together, they point to a conclusion that is difficult to dismiss: that eugenics had only a weak influence upon state welfare directly but arguably a stronger indirect influence that was partly egalitarian and partly inegalitarian. To some extent, then, the welfare state's traditional concern with liberty, equality and welfare may have been based upon reductive conceptions of human nature, e.g. Marshall's view that genetic inequality requires tripartite and selective education. As such, a regulated eugenics must make certain additions which correct that 
reductive emphasis. We are now in a position to outline the remaining two supports of a regulated eugenics.

\section{Towards progressive biopolicies}

According to the multidimensional conception, human nature displays pre-social origins which must be interpreted with social perceptions, meaning that our knowledge of human nature will always be partial and open-ended. Politically, this means supporting the principle of 'differential egalitarianism' which underpins the discussions of recognition and care in Chapter 6 and of deliberative democracy in Chapter 9.

A respect for difference and diversity is required as a reflection of the imperfectability of our knowledge, e.g. we must avoid overprescriptive views of what a meaningful human life involves in order to avoid assumptions regarding normality that invoke homogeneous notions of what it means to be human - with misogynist, disablist and homophobic notions being especially dangerous. Some degree of social equality is also required in order to ensure that that respect for difference is substantive rather than merely formal, i.e. justice requires not only the just distribution of material resources, but also the just distribution of cultural recognition. The principle of differential equality is far from straightforward for, as we saw at the end of Chapter 6 , although distribution and recognition/care overlap, neither can be reduced to the other. A progressive biopolicy therefore requires an application of biotechnology which avoids reductionism by allowing difference-respecting discourses and practices to circulate within socially egalitarian environments. Ultimately, the aim of progressive biopolicies is to maintain the multidimensionality of human nature; the rationale for, and the objectives of, progressive biopolicies therefore resemble one another: the need to avoid the closure of the human condition around homogeneous norms.

This implies that, in addition to the usual values upon which social policy is based - welfare, equality and liberty - a respect for difference demands the addition of a fourth: precaution, i.e. do not institute change for the sake of change, but only if good enough reasons can be found. However, because change can be justified under certain circumstances, the value of precaution is ordered into the following lexical sequence (cf. Suzuki and Knudtson, 1990: 334-5):

\section{Precaution}

1 If it isn't broke, don't fix it. In other words, establish that there is a problem deserving of attention. So much technological innovation involves the construction of problems ex post, i.e. something is defined 
as a problem atavistically in order to justify the time and expense of producing the innovation. We might ask the question recommended by Postman (1993): what is the problem to which this technology is the solution?

2 If it is broke, establish whether the problem is predominantly social or natural.

3 If the problem is social, fix society. In short, we must avoid becoming addicted to technological fixes, as this confers power and responsibility in the hands of scientific, economic and political elites, and may malfunction in ways that require more technological fixes ad infinitum. If the problem is natural, and if a biotech solution seems feasible, then establish a moratorium.

4 Do not end the moratorium without reference to:

(a) Welfare Will the biotechnology fulfil basic needs more effectively? Does a risk assessment reveal that both short-term and long-term risks are at an acceptable minimum?

(b) Equality Will the biotechnology benefit all individuals equivalently?

(c) Liberty Will the biotechnology enhance the liberty of the individual and will it be implemented with the democratic approval of most individuals?

5 If a case is established, then initiate the biotechnology slowly.

6 Initiate more rapid and radical reforms only if (5) is shown not to be working and with additional reference back to (4).

These, then, are the three criticalist supports upon which regulated eugenics rests: multidimensionality, differential egalitarianism and the precautionary principle. Having outlined it in the abstract, and for reasons explained later on, perhaps the best way of understanding regulated eugenics is by contrasting it to the laissez-faire approach in the light of three key social policy issues.

\section{Three dilemmas}

\section{Genetic screening}

The dilemma is simple (Rothstein, 1997; O'Neill, 1998). If people are required either to disclose the results of genetic screening, or to take a test, before receiving health and/or life insurance, then the genetically disadvantaged may be denied cover, or be required to pay excessively high premiums, or deny themselves cover by refusing to take tests that may benefit their health (Rifkin, 1998: 160-9). However, if people are not required to disclose, then insurance companies will suffer from adverse 
selection and the genetically advantaged may have to pay higher premiums than otherwise (Pokorski, 1997).

For the advocates of laissez-faire economics there is no dilemma. In a free market, there is no essential difference between genetic information and the other forms of information that those offering and those seeking insurance exchange in order to gain the best deal for themselves. Companies should be free to require the disclosure of relevant genetic information, setting whatever premiums they see fit, and individuals should be free to either disclose that information or to take their business elsewhere. So long as both insurance providers and insurance seekers act voluntarily in full knowledge of the likely consequences of their actions, then it is not for the state to 'buck' that market.

For those on the Centre-Left, however, such laissez-faire economics engenders a laissez-faire eugenics, where those who are both materially and genetically poor will be doubly disadvantaged. The use of genetic information in a free market will exacerbate inequalities between the most privileged and underprivileged groups that offends against the CentreLeft's conception of social justice, and so it follows that we can longer debate social justice without also debating genetic injustice.

However, genetic screening cannot simply be prohibited, as there are sound medical reasons for its use. Yet we already have an insurance system that permits both adequate, egalitarian cover and genetic screening: social insurance. In a social insurance system, the problems of inadequate coverage and adverse selection disappear because these are non-exclusionary schemes where premiums are uniform and returns are on the basis of need. The solution, then, is either to socialise health insurance where it is still in private hands or at least to require private insurers to behave as if they were social insurers - as is the case in Germany (Wiesing, 1999: 54). The medical benefits of genetic screening may then be utilised, so long as insurance-related problems are dealt with socially and we avoid the complete individualisation of health care that the new genetics could otherwise herald (Hubbard and Wald, 1997). Therefore, we are still engaging in eugenics (because we are making de facto decisions about future generations), but in a regulatory and socialised framework.

A similar contrast between laissez-faire and regulated eugenics can be made in respect of life insurance and employment law. ${ }^{3}$ McGleenan and Wiesing (1999: 116) do not regard the socialisation of life insurance as realistic. If so, we might still require private life insurers to behave as if they were social ones. With some measures against fraud in place, the insurance industry can be left to absorb the potential costs of adverse selection, so long as these costs are moderate, since this is a lesser evil than the risk of genetic discrimination and could be thought of as a sumptuary tax paid by insurers as a necessary side effect of allowing a private market in social 
welfare. Therefore the debate regarding both health and life insurance proceeds no further than principle (3), above (cf. Reilly, 1999). If genetic screening creates problems for the insurance industry, then they are social ones requiring social solutions and not natural ones requiring a biotechnological fix (McGleenan, 1999).

Similar considerations apply to employment (Nuffield Council on Bioethics, 1999). There is a risk that job applicants may either be required to take a test or disclose the results of past tests as a condition of employment. Employers may therefore be tempted to: deny jobs to those who are vulnerable to a slight occupational hazard; only employ those who are less likely to require sick pay and leave entitlements; de-emphasise healthy and safe working conditions. However, employers can argue that screening helps everyone by avoiding the possibility of placing certain workers in jobs to which they are, or may become, unsuited.

What happens if we avoid the laissez-faire approach which in effect means giving employers a free hand? To a large extent, principle (3) is sufficient here also and implies that employers should be required by law to minimise risks that are environmental in origin. However, there may be exceptional cases where the minimisation of environmental risks is still not enough. For the Nuffield Council on Bioethics (1999), this refers to situations where the working environment is inherently dangerous to those with certain genetic conditions, and situations where the welfare of third parties is involved. As such, limited and carefully proscribed forms of screening may be permissible, so long as the values of welfare, equality and liberty are observed. However, screening programmes can only be allowed with substantial reference to principles (4b) and (4c), i.e. those who refuse to be screened and those who, on being screened, are found to possess a potentially dangerous condition, cannot be fired, coerced or refused employment on either of those grounds, unless the interests of third parties are demonstrably at stake. As the BMA (1998: 171) puts it, individuals '. . . should be free to accept certain risks, providing they are informed of the implications and the decision does not put others, who have not consented, at risk'. This also offers protection to the employer whose liability is reduced in those circumstances where genetic screening would have benefited the individual who refused to be screened, or where individuals accepted the risks associated with a revealed genetic condition (Knoppers, 1999: 53).

\section{Gene therapy}

By and large, commentators regard somatic cell therapy as acceptable and germ cell therapy as unacceptable (Suzuki and Knudtson, 1990: 183-91), because whereas manipulation of the former bears implications for the 
individual alone, manipulation of the latter bears implications for the individual's descendants as well. Yet a laissez-faire approach questions this distinction. If I am free to influence and even determine my children's future by providing them with a private education and other social advantages, then why should I not be able to influence/determine their future through genetic intervention as well, whether somatic cell or germ line (Harris, 1998: 173)?

Here the challenge posed by laissez-faire advocates is more substantial than was the case with genetic screening. It is difficult in practice to distinguish fully and adequately between the social and the biological, and between the needs of present generations and the needs of future ones. At present, the consensus seems to be that somatic cell therapy should be permissible for non-cosmetic reasons, i.e. to relieve suffering. Yet, since the lines between the cosmetic and the non-cosmetic and between somatic cell and germ cell therapy are often blurred, it might be that somatic cell therapy could be used to 'improve upon nature' and that gene cell therapy could be permitted were the risks to be calculable. For instance, the BMA (1998: 197-9) supports the consensus view, but allows for the possibility that the terms of the debate may need to alter once genetic technology improves. In short, it recommends the precautionary principle, but allows for the possibility that, once technological advances are in place, the promise of improving individuals' welfare overrides precaution so long as, we might add, the principles of liberty and equality are also closely observed.

However, even if this were to be the case, this does not imply that the relevant decisions should be left to individuals alone. Indeed, it could be said that the engineering of the genetic characteristics of future generations is only permissible in the context of international agreements that set the enforceable limits of individual freedom in this respect. In a free market, predominantly affluent individuals would be able to buy whatever was being offered by private biotechnology companies, leading to the ghettoisation of genetic privilege and underprivilege: the biological equivalents of gated communities and interiorised spaces of private surveillance. If the blurring of the line between the social and the biological demands a consistency on the part of policy-makers, then rather than granting a social and genetic free-for-all, within which affluent parents will come out on top, regulated eugenics requires that the virtue of individual freedom be measured in terms of the effects of free acts upon social equality. In a regulated market, the purchase of genetic advantage would be severely curtailed and largely prohibited, with biotechnology companies being prevented from privatising the human genome through 'life patents' and from monopolising the market in genetic pharmacology. In short, principle (4b) suggests that a laissez-faire market in gene therapy is 
undesirable, even if we one day decide that the somatic/gene cell distinction cannot hold.

\section{Reproduction}

Reproductive freedoms and social diversity are on a collision course. Biotechnology represents a quantum leap beyond existing technologies in its capacity to enhance our control over the reproductive process. Such control can involve the filtering out of undesirable qualities (certain diseases and syndromes) and possibly the 'filtering in' of qualities that are regarded as socially desirable (height, attractiveness, intelligence) though this is a much more remote possibility. At the speculative extreme lies a debate about full human cloning. Full cloning would not involve the creation of armies of automatons, but of individuals who would be genetically identical to their 'nuclear mothers'. For some, this is no more objectionable than the existence of identical twins and test-tube babies; for others, it represents a threat to human identity.

The supporters of laissez-faire genetics/eugenics (Harris, 1998, 1999; Silver, 1998; Beyleveld and Brownsword, 1998) argue that if people wish to have cloned children then, if and when the technology becomes available, why shouldn't they? There are a number of hypothetical situations where the cloning of children can seem fairly unproblematic: (a) to save the life of a dying child by cloning him or her a genetically identical sibling, (b) to allow a lesbian couple to bear a biological child, (c) to allow a single women to have a child without donor insemination. However critics (Putnam, 1999; Wilmut et al., 2000) allege that even these apparently benign examples suggest intractable problems. In scenario (a), the cloned sibling is being treated as a means rather than as an end; in scenario (b), there may be identity problems, e.g. the child might have two biological mothers (a nuclear mother and an egg/womb mother); in scenario (c), the identity problem may stem from the child being both the offspring of the mother and her genetically identical twin. Indeed, if we allow cloning under these circumstances, then why not the cloning of designer babies - a possibility that some laissez-faire advocates view as desirable and unpreventable (Silver, 1998: 141-5)?

It would be easy to relegate this issue to the future until such a time as the technology is either available or has proved to be unrealistic. Unfortunately, even if cloning technology proves to be an unscientific fiction, history shows that bad science does not prevent the design of bad policies and so the ethical debate cannot be sidelined until such time as scientists agree that there either is or is not something real to worry about. Would full cloning be available to all or would the affluent have greater access to this service? In an egalitarian society, we would be faced with 
the above ethical dilemmas only, but in an inegalitarian society we are also faced with the prospect of creating a genetic overclass and underclass. ${ }^{4}$ As Silver (1998: 264) observes: 'If it is within the rights of parents to spend $\$ 100,000$ for an exclusive private school education, why is it not also within their rights to spend the same amount of money to make sure that a child inherits a particular set of their genes?' If such rights are absolute and if social equality is not a consideration, then full cloning may be inevitable; however if, as was argued above, regulated eugenics sets limits on market-based liberties, then biotechnology is as much of an issue for redistributive politics as education, etc. In short, a moratorium is called for because there is a question mark over whether full cloning would satisfy principles (4b) and therefore (4a): cloning should either be available to everyone or to no-one.

However, a moratorium may not be appropriate in all circumstances. Since we may soon have the ability to eliminate certain conditions at the genetic level, do we not have a duty to do so? If we can prevent suffering by eliminating syndromes that offer their bearers only a low quality of life, then why hesitate? The problem is, who is to decide what constitutes a 'low quality of life'? If we allow physical and mental disabilities to be wiped from the human genome, then is this vastly different from the 'designer babies' that so many find distasteful?

There are convincing arguments on both sides. Critics like Shakespeare $(1995,1998)$ invoke the spectre of Nazism and argue that the new genetics may lead to the following. First, a decline in support for all disabled people, as genetic disabilities become rarer. Second, the inference that those who are born bearing such disabilities have lives less worthwhile than the non-disabled. Third, an increase in 'wrongful life' and 'wrongful disability' suits as children sue their parents for the inheritance of conditions that could have been eliminated. Fourth, a reduction in human diversity as 'genetic correctness' becomes the norm. Finally, the possibility that genetic engineering starts with the elimination of medical defects and ends with the elimination of 'social defects' (criminals, homosexuals, etc.). Therefore biotechnology represents a quantum leap beyond existing forms of selective abortion. However, supporters like Buchanan (1993, 1996; Harris, 1998; Buchanan et al., 2000) raise a number of counterarguments. First, avoidable suffering should be eliminated whenever possible - if we ban genetic engineering then should we not ban non-genetic techniques on the same grounds? Second, parents should have the right to know the genetic characteristics of their children and make appropriate decisions. Third, eliminating genetic disabilities need not lead to the devaluation of disabled people. Finally, if social justice requires the redistribution of undeserved social advantages, then does it not also demand the elimination of undeserved genetic disadvantages? 
How can we decide between these positions, when 'difference' implies a respect for social diversity yet 'equality' requires us to reduce suffering? There would appear to be three basic options. First, we could ban prenatal testing in almost all cases. This means that there should be no intervention into the genetic characteristics of future generations. The problem with this option is that we already interfere with nature in attempting to reduce suffering. If our genetic natures are interdependent with our social environments, then the injunction to 'not interfere' might imply that we are no more allowed to manipulate the latter than the former. In fact, this option is a kind of 'naturalist laissez-faire', where the price for our occupying the moral high ground of non-interference will be paid by those experiencing debilitating genetically-related conditions.

Second, we could adopt the other form of laissez-faire whereby we allow parents to make whatever commercial decisions they wish based upon whatever information is technologically available at that time. As we have already argued though, this is to ignore the end-states of market exchange and to invoke an anti-social libertarianism that is reminiscent of Nozick (1974). Given the prejudices that too many people hold, this 'anything goes' approach might open the floodgates to the casual holocaust that those such as Shakespeare warn us against.

Finally, we could apply a regulated approach. This attempts to both reduce suffering and respect the diversity of human experience. Achieving both goals involves a balancing act so difficult that we may never get it quite right. In fact, unlike the above options, this approach can only be partly formulated in the abstract, prior to its application in the real world. The principles of regulated eugenics only become meaningful and fully comprehensible through their application. Therefore the establishment of a regulatory framework requires a perpetual, deliberative debate: a reflective, democratic discourse between scientific and policy experts and the lay public. That said, my own suspicion is that we should err on the side of caution (the precautionary principle): just as pleasure does not necessarily denote the presence of a minimal quality of life, so pain does not necessarily denote its absence. This places regulated eugenics far closer to Shakespeare's position than to that of Buchanan and implies that certain limits should be placed on reproductive rights, e.g. if it were possible to reveal sexual orientation through prenatal testing, then the continuance of homophobic prejudice suggests that testing should not be used for this purpose (Stein, 1998). Second, reproductive decisions should not be a substitute for social justice. Even the slightest suspicion that biotechnology will be used against the poor and/or against social diversity means that its use should be internationally banned. 


\section{Whose posthuman future?}

Because his eyes do not swivel half as rapidly as Murray's, there is probably much in the above with which Francis Fukayama would agree. For all of the usual simplicities into which his analysis falls, (Orwell is treated as a soothsayer who 'got it wrong' apparently) Fukayama (2002: 99-100) wishes to resist the libertarian drift towards posthumanism and to defend an international regulation of biotechnology. Nevertheless, Fukayama's position rests upon foundations that are weak in two critical senses.

First, his is a sort of 'reluctant collectivism' in which regulation is treated as the least-worst option: 'The inefficiency of any scheme of regulation is a fact of life' (Fukayama, 2002: 184). But if the default position is assumed to lie always with deregulation and if the burden of proof weighs heavily upon those who would regulate, then Fukayama is effectively undermining the very case that he seeks to make. By introducing premises that emphasise the costs rather than the social benefits of regulation, Fukayama trips over his own feet. From a European perspective, those benefits are much more visible (Hutton, 2002).

Second, and more importantly, Fukayama adopts a form of conservative naturalism that dichotomises the debate while claiming to avoid the extremisms of others:

There are good prudential reasons to defer to the natural order of things and not to think that human beings can easily improve on it through casual intervention. (Fukayama, 2002: 97)

... human nature is the sum of the behaviour and characteristics that are typical of the human species, arising from genetic rather than environmental factors. (Fukayama, 2002: 130)

But even if we accept that for instance IQ is determined by genetics by a factor of 40 to 50 per cent (Fukayama, 2002: 137), then this means that environment would still outweigh it by a factor of 50 to 60 per cent. So even according to the research which Fukayama favours, we have little reason to define human nature in such reductionist terms or to 'defer to the natural order of things'.

Therefore although Fukayama demands the regulation of biotechnology his underestimation of the social and of the benefits of social goods means that his bias is always in favour of the status quo. His is a kind of 'evolutionary communitarianism' where, 'Human beings have been wired by evolution to be social creatures who naturally seek to embed themselves in a host of communal relationships' (Fukayama, 2002: 124). Regulation is needed so that we avoid excessive interference with human nature and so preserve the future for liberal democratic capitalism. This 
differs from the regulated eugenics defended above for two reasons. First, because if we accept the concept of emergent properties where the later stages of evolution are more than the sum of the earlier ones, then culture cannot be treated merely as an evolutionary effect of nature. This means that 'the social' is more important than Fukayama can admit. Second, we do not have to believe that humans are 'infinitely plastic' to advocate greater intervention than Fukayama (2002: 13-14) allows; nor is it the case that excessive intervention is necessarily due to an anti-naturalistic bias: the communist experiment that Fukayama abhors occurred not because human nature was ignored, but because the commissars believed that they, and only they, truly understood the nature of nature, a conceit remarkably close to that held by the Right.

Therefore, although his support for regulation is welcome, Fukayama misses the Left's central contention: that biotechnology is permissible if and only if it serves the goals of attention, sustainability and (we may as well add) distributive justice. The Left does not have to advocate genetic engineering as a form of redistribution, nor does it have to abandon its preference for explanations that favour the social over the natural (Fukayama, 2002: 159-60); it simply has to challenge the biological reductionism upon which the Right's case is ultimately made as unfortunately is Fukayama's. So although the politics of biotechnology does not fall neatly into familiar political categories, those categories are rendered nowhere near as redundant as Fukayama (2002: 211) imagines.

\section{Conclusion}

The conclusion then is this: we should only be allowed to improve human well-being through biotechnology if we are also prepared to improve it through the implementation of policies based upon distributive justice and attention (the recognition of and care for diversity). This is the central insight that social policy has to offer the biotechnology debate: just biopolicies require the maintenance of just welfare systems. The recent history of welfare reform therefore gives cause for concern and suggests that biopolicies are currently more likely to follow a regressive path that we have all too often been down before.

Since this path is arguably one down which New Labour have been leading us, as Chapters 2 and 3 argued, then it is necessary to conceive of alternative routes. So whereas they have interpreted information as asocial, commodified and as a source of surveillance, this chapter has sketched a different approach. Here, information is regarded as embedded in the complexities of social relations, as a feature of the mediated interaction between human nature and its environment, as that which 
cannot be abstracted from its context into commodified forms of exchange without alienating the beings to whom the information belongs, as that which should not be used for the purposes of surveillance (especially in the field of health care) unless the information is itself subject to surveillance and control by social equals through open, accountable institutions and systems of discourse.

\section{Notes}

1 'Self-interest' is a more accurate term than 'selfishness' because, as Mary Midgely (1995: 91) observes, the latter attributes motivation to bits of goo. The metaphor though shows no signs of fading and has landed Dawkins in well-deserved trouble on numerous occasions.

2 Note: this is not to claim that such systems have not been also inspired by other motives.

3 Long-term care is also relevant in this context (Lenaghan, 1998: 113-14), but this is here left to one side as the regulatory solution is substantially the same as for health and life insurance.

4 As a means of avoiding this, Steiner $(1994,1999)$ recommends that the genetically advantaged pay a 'genetic tax' into a global fund for redistributive purposes. 